\title{
65歳以上の高齢者大腸癌症例の検討
}

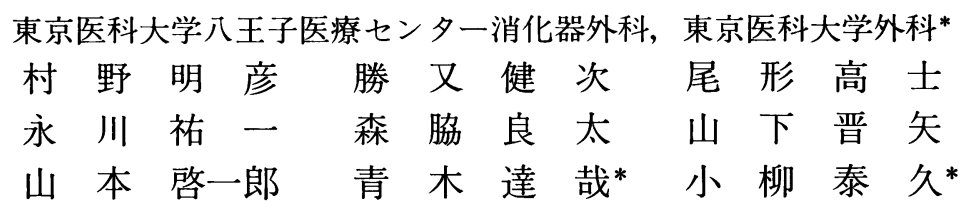

\section{Studies on Colorectal Cancers in The Aged Patients of over 65 Years Old}

\author{
Akihiko MURANO, Kenji KATSUMATA, Takashi OGATA, \\ Yuuichi NAGAKAWA, Ryouta MORIWAKI, Shinya YAMASHITA, \\ Keiichirou YAMAMOTO, Tatsuya AOKI* and Yasuhisa KOYANAGI* \\ Department of Gastro-intestinal Surgery, Hachiouji Medical Center of Tokyo Medical College, \\ Department of Surgery, Tokyo Medical College*
}

高龄者大腸癌を定義するためにD 2, D 3 郭清を行った65歳以上の大腸癌症例の臨床病理学的因子, 術前後合併 症, 予後を検討した。初回待期手術症例で 65 歳以上のD 2 以上の郭清を行った大腸癌患者 92 例を对象とし, A群 $(65$ -74歳； $\mathrm{n}=59)$, B群 $(75-87$ 歳; $\mathrm{n}=33)$ を検討した。臨床病理学的にStageIVと根治度C症例は各々 A群 $(8.5 \%$, $8.2 \%)$ に比べB群 $(33.3 \% ， 24.2 \%)$ で有意に多く, 術前合併症は\%VCが $80 \%$ 未満, 24 時間Ccrが $70 \mathrm{ml} / \mathrm{dl}$ 未満 の症例は各々B群 $(24.1 \%, 88.5 \%)$ でA群 $(1.7 \% ， 37.5 \%)$ に比べ有意に多かった。術後合併症は, 不穞がB群 (36.4\%) でA群 (8.5\%) に比べ有意に多いが縫合不全等に差はなかった。 5 年生存率は両群間の根治度A症例 で差がなく, 術中出血量, 手術時間, 平均術後在院期間, 平均離床期間も各群間で有意差は無かった。以上, D 2 , D 3 郭清をした65歳以上の治癒切除症例で両群間の 5 年生存率に有意差が無いため, 高齢者に治癒切除を行うべ きであり，また，75歳以上を高㱓者とするのが妥当と思われた。

索引用語 : 高齢者 (the elderly), 大腸癌 (colorectal cancer), リンパ節郭清 (lymph node dissection), 術後 合併症 (post operative complication)

\section{はじめに}

最近の消化器外科手術において高齢化社会を反

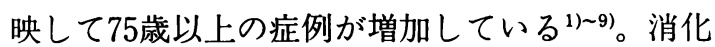
器癌の手術内容は術式の確立, 手技の進歩, 麻酔 管理の向上により高齢者に対しても積極的な郭清 をしている施設がみられる26)10111) 13), 高齢者大腸 癌症例の手術治療においても充分な郭清を施行す ることは癌の根治度を高める上で必要であり, 癌 の進行度に応じD 2, D 3 郭清が行われる傾向にあ

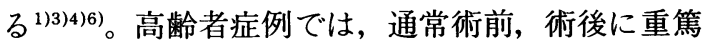
な合併症がみられたり，不測の経過をとることも あり十分な注意が必要であるが714), 適切な術後管 理により合併症の発生率を抑之得る可能性を示唆

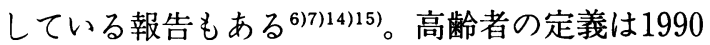
年以降になると, 70歳以上とするもの ${ }^{16) 17)}, 75$ 歳以

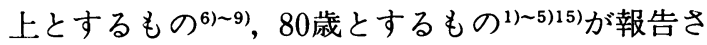
れているが，75歳以上と定義する報告が多い。70 歳代のリンパ節郭清については生存期間の延長が 得られるという報告がある2)。今回，われわれは高 
齢者大腸癌症例の特徵を明らかにするためにD 2 以上の郭清を行った 65 歳以上の症例の臨床病理学 的因子, 術前併存症, 術後合併症, 予後等につい て検討し，65歳から74歳までの症例に比べ呼吸器 障害, 腎障害, 術後不稳やstageIV症例の多い75歳 以上の大腸癌症例を比較検討した。

\section{対象および方法}

1991年 1 月から1996年12月に東京医大八王子医 療センターで初回の待期手術を受け，コらに術前 に重複癌を認めていないD 2 以上の郭清を行った 65歳以上大腸癌症例92例老対象とした。これらの 症例を $\mathrm{A}$ 群 $(65-74$ 歳； $\mathrm{n}=59), \mathrm{B}$ 群 $(75-87$ 歳; $\mathrm{n}=$ 33）の 2 群に分け, 術前合併症の有無, 臨床病理 学的因子, 組織学的進行度, 根治度, 手術術式, リンパ節の郭清度, 手術時間, 術中出血量と術後 合併症の有無, 術後在院期間, 離床期間, 予後等 について比較検討した。

統計処理はT検定およびx 2 検定を使用し， P $<$ 0.05を統計学的な有意差と判定した。また，累積 生存率の算出はKaplan-Meier法を用い，5年生 存率の有意差はlogrank検定を使用した。

\section{結 果}

\section{1. 臨床病理学的所見}

A群は男性39例, 女性20例, 平均年齢69.6歳で, B群では男性17例，女性16例，平均年齡78.6歳でA 群に男性が多い傾问がみられた。

占居部位は，A群，B群で結腸癌の占める割合が 各々24例 $(40.7 \%) ， 20$ 例 $(60.6 \%)$ でA群に比べ B群で多く有意差を認めた $(\mathrm{P}<0.0064)$ 。同時性大 腸多発癌症例は B群で 1 例に認め横行結腸 $S$ 癌, 直腸にsm癌を認めた。

組織学的進行度ではA群, B群でStageIVであっ た症例が各々 5 例 (8.5\%)，11例 (33.3\%) にみ られB群に多く有意差を認めた $(\mathrm{P}<0.0057)$

(Table 1)。

Dukes分類ではA群, B群で各々Dukes Dが 4 例 (6.8\%)，11例 (33.3\%), Dukes Cが23例 (39.0 $\%$ ， 11例 (33.3\%), Dukes Bが6例 (10.1\%), 1 例 ( $3 \%$ ), Dukes Aが26例 (44.1\%), 10例 (30.3 \%) でDukes DがB群に多く有意差を認めた $(\mathrm{P}<$
$0.0057)$ 。

各群の組織惊召分化型腺癌と中分化型腺癌が頻 度が多く $\mathrm{A}$ 群, $\mathrm{B}$ 群の高分化腺癌の頻度は, 各々 30 例 $(50 \%) ， 17$ 例 $(51.5 \%)$ で，一方，中分化型腺 癌では26例 $(43.3 \%) ， 11$ 例 $(33.3 \%)$ であった。 また，A群， B群では粘液癌が 3 例 (5.1\%)，4例 (12.1\%)にみられたが有意差は認めなかった (Fig. 1)。

\section{2. 術前評価}

（血液生化学検查，呼吸機能，腎機能，心機能， およびASAの全身状態分類)

術前合併症は年齢が高くなるはど呼吸器障害, 繁機能障害のある症例が増加した。呼吸器障害で は，拘束障害 (\%VCが80\%未㳑)のある症例がA

Table 1 Patients characteristics

\begin{tabular}{|c|c|c|c|c|}
\hline \\
\hline & \multicolumn{2}{|c|}{ Group $A(n=59)$} & \multicolumn{2}{|l|}{ Group $B(n=33)$} \\
\hline sex; male/female & \multicolumn{2}{|c|}{$39 / 20$} & \multicolumn{2}{|l|}{$17 / 16$} \\
\hline Mean age & \multicolumn{2}{|c|}{69.7} & \multicolumn{2}{|l|}{78.6} \\
\hline Range & \multicolumn{2}{|c|}{$65-74$} & \multicolumn{2}{|l|}{$75-87$} \\
\hline \multicolumn{5}{|l|}{ Location } \\
\hline C & 9 & & 4 & \\
\hline A & 1 & 33 & 8 & 21 \\
\hline $\mathbf{T}$ & 5 & & 3 & $p<0.0064$ \\
\hline D & 3 & & 1 & \\
\hline$S$ & $15-$ & & $5-$ & \\
\hline R & 26 & & 12 & \\
\hline
\end{tabular}

$\begin{array}{cccc}\text { Histological stage } & & & \\ \text { O } & 1 & 1 & \\ \text { I } & 12 & 2 & \\ \text { II } & 18 & 8 & \\ \text { IIIa } & 16 & 4 & \\ \text { III } & 7 & 7 & \\ \text { IV } & 5 & 11 & * 0<0.0057 \\ \text { Dukes A } & 5 & & \\ \text { B } & 26 & 10 & \\ \text { C } & 6 & 1 & \\ \text { D } & 23 & 11 & \\ & * 4 & * 11 & * p<0.0057\end{array}$

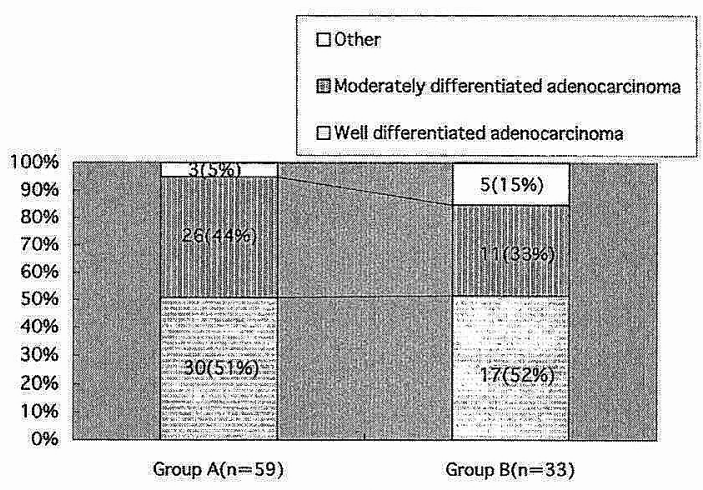

Fig. 1 Histological type 
群，B群で各々 $1.7 \%(1 / 58) ， 24.1 \%(7 / 29)$ に みられA群に比較しB群で有意に多く認められた $(\mathrm{P}<0.0026)$ 。

また，24時間 $\mathrm{Ccr}(24 \mathrm{Ccr})$ でみる腎機能检査は $24 \mathrm{Ccr}$ が70 ml $/ \mathrm{dl}$ 未満の症例が $\mathrm{A}$ 群, B群で各々 $37.5 \%(18 / 48) ， 88.5 \%(23 / 26)$ に乎られA群に 比較しB群に有意に多く認められた $(\mathrm{P}<0.05)$

また，高血圧は各群に各々 $17.2 \%(10 / 59) ， 24.2$ \% (8/33) 老認めB群に多い傾向がみられたが有 意差はなかった (Table 2)。

ASA (American Society of Anesthesiologists, Physical status [ASC PS： 1-6]) 分類に㧈い て高齢者はPS -2 として扱う。高齢者をRisk Factor方ら除いた場合，A群，B群のPS- 1 は各々 30\%

(18/59), 15\%(5/33)で, PS-2は63\%(37/59), 64\% (21/33)で, PS-3は $7 \%(4 / 59), 21 \%(7 /$ 33）でA群とB群の間に有意差は認めなかった

(Fig. 2)。一方，高齢者をPS- 2 として扱った場 合, A群, B群のPS 1 は30\% (18/59), $0 \%(0 /$ 33）で, PS- 2 は各々 $63 \%(37 / 59) ， 79 \%(26 / 33)$ であった。

\section{3. 手術術式, 根治度, リンパ節郭清度}

各群における根治度Aの割合はA群 $81.7 \%$ (48) 59), B群60.6\% (20/33) でA群で多く有意差がみ られた $(\mathrm{P}<0.05)$ 。一方, 根治度C症例はそれぞれ 8.3\% (5/59)，24.2\% (8/33) でA群に比べB群 に多い傾向が見られたが有意差は認めなかった

(Fig. 3)。リンパ節郭清仕D 2 郭清老行った症例 がA群，B群で各ふ33.3\% (20/59)，44.4\% (14) 33）でD 3 郭清を行った症例が各々66.7\% (39/ 59)，55.6\% (19/33) で有意差は認女なかった

Table 2 Risk factors of patients

\begin{tabular}{|c|c|c|c|}
\hline Risk factors & Group $A(n=59)$ & Group $B(n-33)$ & \\
\hline $\begin{array}{c}\text { Cerebrovascular } \\
\text { disease }\end{array}$ & 1 & 1 & \\
\hline \multicolumn{4}{|l|}{$\begin{array}{l}\text { Respiratory } \\
\text { dysfunction }\end{array}$} \\
\hline$\% \vee C 80 \downarrow$ & ${ }^{*} 1 / 58$ & $* 7 / 29$ & ${ }^{*} \mathrm{p}<0.0026$ \\
\hline FEV $1.0 \% 70 \downarrow$ & $5 / 58$ & $3 / 29$ & \\
\hline Hypoproteinemia & 3 & 2 & \\
\hline Cardiac dysfunction & 3 & 5 & \\
\hline Anemia & 26 & 20 & \\
\hline Diabetes mellitus & 5 & 3 & \\
\hline Liver dysfunction & 3 & 2 & \\
\hline Hypertension & 10 & 8 & \\
\hline \multicolumn{4}{|l|}{ Renal dysfunction } \\
\hline $24 \mathrm{Ccr} 70 \downarrow$ & ${ }^{*} 18 / 48$ & ${ }^{*} 23 / 26$ & ${ }^{*} \mathrm{p}<0.05$ \\
\hline
\end{tabular}

(Table 3 )。

\section{4. 術後合併症}

A群，B群における術後合併症は，不穞が各々 $8.5 \%(5 / 59) ， 36.4 \%(12 / 33)$ によれA群に比 べB群で有意に多かった $(\mathrm{P}<0.006)$ 。術後合併症 のみられなかった症例は $\mathrm{A}$ 群，B群で各々 $72.9 \%$ (43/59)，42.4\% (14/33) でB群に比べA群で有 意に多かった $(\mathrm{P}<0.001)$ 。

縫合不全はA群, B群で各々 3 例, 1例でみられ た。A群の 3 例はS 状結腸癌 2 例, 直腸癌 1 例で, このうち 1 例は膀胱全摘出術を行った回腸導管の 縫合不全であった。B群の1例は直腸癌症例で, 80 歳以上の症例では縫合不全起認めなかった (Table 4)。

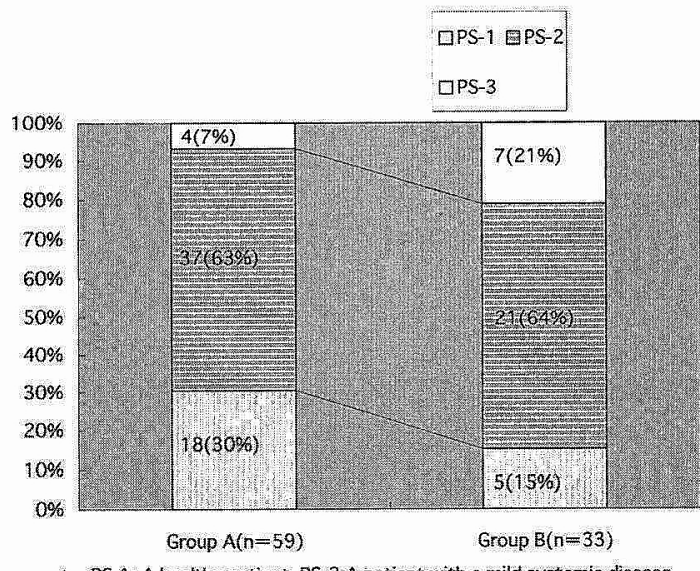

* : PS-1: A healthy patient, ES-2;A patient with a mild systemic disease, PS-3; A patient with severe systemic disease that limits activity, but is not incapacitating.

Fig. 2 Physical Status

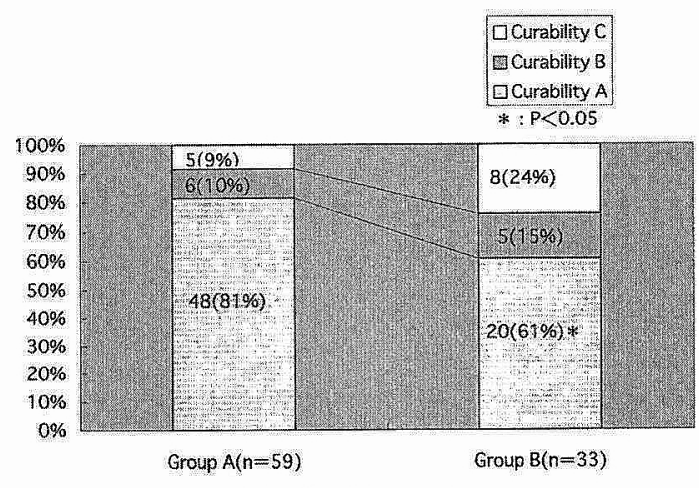

Fig. 3 Curability 
Table 3 Operative procedure Group $A(n=59) \quad$ Group $B(n=33)$

$\begin{array}{lrr}\text { lleocecal resection } & 3 & 0 \\ \text { Right hemicolectomy } & 11 & 14 \\ \text { Left hemicorectomy } & 5 & 2 \\ \text { Sigmoidectomy } & 8 & 4 \\ \text { Low anterior resection } & 21 & 11 \\ \text { APR } & 7 & 0 \\ \text { Hartmann's operation } & 4 & 2 \\ \begin{array}{l}\text { Combined resection } \\ \text { Yes }\end{array} & & \\ \text { Lymph node dissection } \\ \quad \text { D2 } \\ \text { D3 }\end{array}$

* : APR; abdominoperineal combined resection.

Table 4 Postoperative complication

Mental disorders
Respiratory dysfunction
Wound infection
lleus
Anastomotic
insufficiency
Anastomotic stenosis
Arthymia
Liver dysfunction
Renal dysfunction
Sepsis, MOF
Abdominal angina
Bleeding
No complication

$\begin{array}{ccc}\text { Group } A(n=59) & \text { Group B(n=33) } \\ 5 & 12 & \\ 0 & 1 & \\ 0 & 3 & \\ 2 & 1 & \\ 0 & 1 & \\ 3 & 1 & \\ & 5 & \\ 0 & 0 & \\ 2 & 1 & \\ 2 & 1 & \\ 1 & 0 & \\ 5 & 1 & \\ 1 & 14 & p<0.001\end{array}$

\section{5. 術中出血量, 手術時間, 術後在院期間, 離床 期間}

$\mathrm{AB}$ 各群間の術中出血量及び手術時間は各々 $695 \mathrm{ml}, 573 \mathrm{ml}$ 及び214分，201分で有意差がなかっ た。また，平均術後在院期間は，各々 30.5 日，29.8 日でおよそ30日前後で, 平均離床期間は 4.6 日, 4.7 日であった。この両群間での有意差は無かった

\section{(Table 5 )。}

\section{6. 予後}

在院死及び他病死を除いたlogrank検定による 根治度 $\mathrm{A}$ 症例の 5 年生存率は $\mathrm{A}$ 群 $(\mathrm{n}=43)$, B群 (n=18）で有意差はなかった（Fig.4）。根治度 A症例の 2 年生存率はA群，B群で各々 95\%（42/ 44)，95\% (18/19) で有意差はなく，根治度B症例 ではA群，B群で100\% (6/6)，60\%（3/5) と A群に高い傾向を認めたが有意差はなかった。根 治度 $\mathrm{A} 及 ひ ゙ B$ 症例の死因はA群, B群で各々で 1 例 ずつに局所再発を認め, 残りの 5 症例は癌性腹膜
Table 5 Operative factors and hospital stay

$\begin{array}{lll} & \text { Group } A(n=59) & \text { Group } B(n=33) \\ \text { Bleeding(ml) } & 678.6 & 573.1 \\ \text { Operative time(min) } & 214.5 \pm 60.9 & 201.2 \pm 71.6 \\ \text { Hospital stay(days) } & 30.5 \pm 11.4 & 29.8 \pm 14.3 \\ \text { Lying in bed(days) } & 4.6 \pm 2.6 & 4.7 \pm 2.3 \\ \begin{array}{c}\text { Epidural anestesia } \\ \multicolumn{1}{r}{\text { Yes }}\end{array} & 49 & 28\end{array}$

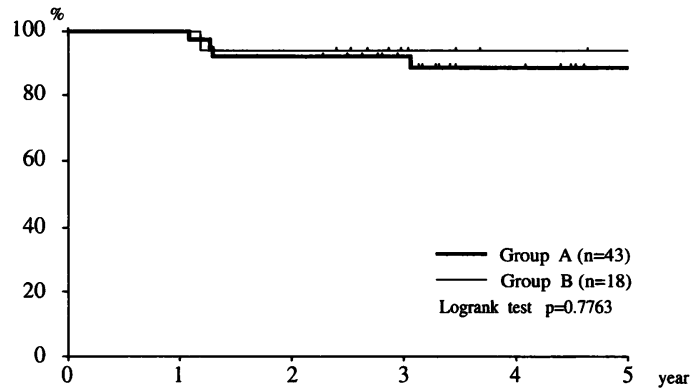

Fig. 45 year survival rate

Table 6 Prognosis

$\begin{array}{lcc}\text { Operative death } & \text { Group } A(n=59) & \text { Group } B(n=33) \\ \begin{array}{l}\text { Hospital death } \\ \begin{array}{l}\text { year survival rate } \\ \text { absolute curative resection }\end{array}\end{array} & 42 / 44 & 1 \\ \text { relative curative resection } & 6 / 6 & 18 / 19 \\ & 4 & 3 / 5\end{array}$

炎であった。手術後 1 力月以内に死亡した症例(術 死) はB群に 1 例を認めただけで，死因は縫合不全 に起因したMOFであった。在院死はA群で 4 例に みられたがB群には見られなかった。この原因は 各々肝硬変に伴う肝不全, 誤飲性肺炎からの呼吸 不全，上腸間膜動脈閉塞症による敗血症，および 腹腔内出血に起因するDICであった（Table 6 ）。

\section{考察}

1997年 8 月の厚生省の報告では，日本人の平均 寿命が男性76.3歳，女性82.8歳でわが国の高齢化 社会を表しており，高齢者人口の増加に伴い高齢 者大腸癌の占める割合も増加傾向にある ${ }^{18)}$ 。手術 対象としての高齢者の年秢とは何歳を指すのか手 術治療に際し高齢者の定義が必要である。石橋ら は累積 5 年生存率に有意差がでる最低年齢から高 齢者結腸癌を定義し77歳以上の年齡が高齢者であ 
るとしているが19), 最近の報告によれば高齢者を 70歳以上とするもの ${ }^{15) 16)}$, 75歳以上とするも の $^{6) \sim 9)}$ ，80歳以上とするものがある ${ }^{1) \sim 5) 15) 。 ま た, ~}$ 85歳以上を超高齢者として報告しているものもあ $3^{20)}$ 。ここで高齢者を定義すれば, 日本人の平均寿 命が男性76.3歳で, 累積 5 年生存率に有意差がで る最低年歯が77歳，さらに75歳以上を高齢者とす る報告が最も多いなどの理由から75歳以上を高齢 者とするのが適当であると考える。

一方, 厚生の指標によれば 65 歳以上の人口を老 年人口と規定しているが, 上記の理由で75歳以上 を高齢者とすれば自験例では術前, 術後に合併症 を有する割合が65歳から74歳と75歳以上の症例で 明らかに異なっている。術前の呼吸障害, 腎障害 や術後の不稳, 術後合併症の発生頻度は75歳以上 の症例で有意に多くこの点でも75歳以上を高齢者 と考之られる。今回, われわれは65歳から74歳と 75 歳以上の治癒切除症例の 5 年生存率について検 討した。この結果, 75歳以上の症例は65歳から 74 歳に比べ合併症などのリスクが高いが治癒切除す ることで65歳から 74 歳の症例の 5 年生存率と有意 差がなかった。

今回，われわれはASA分類 (American Society of Anesthesiologists, Physical status [ASA PS：1-6]）を使用して術前の患者の全身状態評 価を行った。術前の全身状態の評価基準である ASA分類では, PS- 1 は健康な患者, PS- 2 は日常 生活に支障のない程度の全身疾患を持っている患 者, PS- 3 は生活制限を要する程度の重度の全身 疾患を持っている患者とされており，われわれの 症例は全例がPS- 1 からPS- 3 に分類された ${ }^{21}$ 。 この評価基準では, 高齢者をPS- 2 として扱って いるが, 今回, 高齢者をPS- 2 より除いて評価した 場合, $\mathrm{A}$ 群, $\mathrm{B}$ 群で有意差を認めなかった。

手術に関して以前は高齢者に対し縮小手術が選 択されていたが, 最近ではD 2 以上の郭清を施行 した症例の報告も増えている。石田らによれば高 齢者のリンパ節郭清の意義については年齢により 異なるとしており，70歳代ではD 2 以上の郭清で 生存期間の延長が得られ, また, 80歳から84歳で もD 2 以上の郭清で有意差はないが生存期間が延 長する傾向があると報告している ${ }^{2)}$ 。一方, 80 歳以
上の胃癌に対する縮小手術による直接成績では, 年㱓的な差がみられないが遠隔成績において癌再 発が多くなる傾向が報告されている3 。さらに, 大 腸癌症例でも同様の報告がある5)。このような理 由から高齢者大腸癌症例に対しても年齢と病期に 応じた術式の選択が必要と考えられる。当然, 治 療上は充分なリンパ節郭清を伴った手術が有効な 手段であるが，郭清に伴う侵襲は高路者にとって 術後合併症を高める可能性があり大きな問題とな る。近年, mp癌に関して至適リンパ節郭清につい ての報告が多数なされているが, 進行癌では, ま だ一定の見解が確立されていない22),23)。年齢, 全身 状態，QOL等を考慮した高齢者手術に対する至適 なリンパ節郭清術を行う事は, 更に複雑で難解な 問題である。高齢者で高率にみられる術後合併症 は肺炎，せん妄であるが高齢者であっても十分な 術後管理を行えば根治度の高い術式が可能である と思われる67710)15)。今回のわれわれの報告でも根 治度 $\mathrm{AB \mho ゙B}$ 症例は $\mathrm{A}, \mathrm{B}$ 群の両群で不稳を除いた 術後合併症の発生率や 2 年生存率において有意差 がなく, 治癒切除により高齢者でも同様の生存期 間の延長が得られる事が期待される。

手術術式と再建方法についても施設によりさま ざまな工夫が行われている。たとえば，80歳以上 の症例であっても術前に明らかなrisk factorがな くADLの若い症例で, 肛門機能, 排尿機能に問題 の少ない症例は, 根治性の高い機能温存手術を適 応すべきである。一方，高齢者でリスクの高い症 例では，根治性を追求し縫合不全を考慮しなくて もよいハルトマン氏手術を積極的に行っている施 設もある15)。消化器癌における縫合不全は重篤な 合併症であり，高齢者においては致命的となる場 合がある。当院でも直腸癌症例に縫合不全を認め ており，少なくとも高齢者ではハルトマン氏手術 を念頭においた手術選択も必要であると考えられ る。

\section{結語}

1. D 2, D 3 郭清を行った65歳以上の大腸癌症 例の臨床病理学的因子, 術前術後合併症, 予後に ついて検討した。

2.75歳以上の高齢者症例は呼吸器障害, 腎障 


\section{日本外科系連合学会誌 第 24 巻 5 号}

害, Dukes D症例や術後の不穞を多く認めるなど の特徵があり，75歳以上を高㱓者と定義すべきと 判断した。

3. 高齢者直腸癌症例では, 機能温存術も充分 考虑しphysical statusに応じてハルトマン氏手術 を念頭においた手術術式の選択が必要である。

4.D 2 以上の郭清を行った75歳以上の治癒切 除症例では 2 年および 5 年生存率に両群間で有意 差がなく, 生存期間の延長が期待されるため高齢 者においても治癒切除を考慮した術式を選択すべ きであると思われた。

\section{参考文献}

1）田島秀浩, 西村元一, 宮崎逸夫他：高齢者大腸癌 の検討。 日本大腸肛門病会誌 $48: 521-525,1995$

2) 石田秀行, 岩間殼夫, 三島好雄他：80歳以上高齢 者大腸癌に対するリンパ節郭清・他藏器合併切除 術の意義. 日消外会誌 $29 ： 2058-2063 ， 1996$

3）湊 博史, 沢井清司, 大原都桂他：高齢者胃癌の 問題点一とくに80歳未満と 80 歳以上の治療方針 の差異について一. 日消外会誌28：987-992, 1995

4）石神純也, 山田一隆, 朝沼 榎他: 高齢者大腸癌 の外科治療について。 日消外会誌27：1961-1967, 1994

5）柴田信博，野口貞夫：10年間における高齿者（80 歳以上) 大腸癌の治療成績. 日臨外医会誌 $52: 737$ $-740,1991$

6）川堀勝史, 岡島正純, 有田道典他：高齢者大腸癌 の臨床病理学的特徵と遠隔成績. 日本大腸肛門病 会誌 $48 ： 206-211 ， 1995$

7）国崎主税，小林俊介，今井信介他：高齢者（75歳 以上) 大腸癌の臨床病理学的検討一 55 歳以上 65 歳 未満の大腸癌と比較して一. 日本大腸肛門病会誌 $48: 526-533,1995$

8）桜井洋一, 青木明人, 岡芹繁夫他: 高齢者大腸癌 切除例の臨床病理学的特徵とその遠隔成績一若· 壮年者大腸癌症例との比較を中心に一. 日臨外医 会誌 $51 ： 1418-1425,1990$

9）亭川公章, 安積靖友, 磯 篤典他：高秢者大腸癌 の臨床病理学的検討. 日本大腸肛門病会誌 $43: 50$ $-55,1990$
10）久保 章, 高橋利道, 岩田誠一郎他：高齢者大腸 癌症例の検討. 横浜医 $47 ； 573-578,1996$

11）内田信之, 小坂橋宏, 長町幸雄他：高齢者（80歳 以上）の胃癌, 大腸癌の検討一とくに術後合併症 を中心に一。日臨外医会誌 $55 ： 1947-1952 ， 1994$

12) Lewis AAM, Khoury GA : Resection for colorectal cancer in the very old: are the risks too high? Br Med J 296 : 459-461, 1988

13) Agarwal N, Leighton L, Mandile MA et al: Outcomes of surgery for colorectal cancer in patients age 80 years and older. Am J Gastroenterol 85 : 1096-1101, 1990

14) Houry S, Amenabar J, Rezvani A et al : Should patients over 80 years old be operated on for colorectal or gastric cancer? Hepato Gastroenterol $41: 521-525,1994$

15）井原 厚, 大谷剛正, 国場幸均他：80歳以上高齢 者大腸癌症例の検討. 北里医 $23: 22-29,1993$

16）二村 学, 横尾直樹, 北角泰人他：高齢者大腸癌 手術症例の検討一術前術後合併症から見た高齢 者の位置付け一。 日臨外医会誌 $57: 2634-2640$, 1996

17）渋谷 均, 西尾昭彦, 西田陸夫他：高齢者大腸癌 の検討。日臨外医会誌 $51 ： 1186-1190 ， 1990$

18）厚生統計協会編：厚生の指標『国民衛生の動向』. 平成 9 年度版. 財団法人厚生統計協会, 東京, 44 (9) : 78, 1997

19）石橋敬一郎, 芳賀駿介, 遠藤俊吾他：生存率から みた高齢者結腸癌の定義に関する検討.日消外会 誌29：2064-2068，1996

20）武川 悟, 長濱 幌, 富木裕一他：超高齢者大腸 癌切除症例の検討。日臨外医会誌 $57 ： 2624-2645$, 1996

21) American Society of Anesthesiologists: Newclassification of physical status. Anesthesiology $24: 111,1989$

22）安井信隆, 渡邊昌彦, 寺本龍生他: 大腸 $\mathrm{mpがんに}$ 対するリンパ節郭清範囲に関する検討. 日消外会 誌 $29 ： 1995-2001 ， 1995$

23）小山靖夫, 国武健二郎：全国集計からみた大腸 $\mathrm{mp}$ 癌の現状. 胃と腸 $27 ： 1253-1259,1992$ 